\title{
Locally Advanced Adrenal Gland Pheochromocytoma
}

National Cancer Institute

\section{Source}

National Cancer Institute. Locally Advanced Adrenal Gland Pheochromocytoma. NCI

Thesaurus. Code C157129.

Adrenal gland pheochromocytoma that has spread from its original site of growth to nearby tissues or lymph nodes. 